\title{
Musical Archaeologists: The Revival and Reconstruction of Polyphonic Masses in Corsica
}

DOI:

10.1080/17411910600634395

\section{Document Version}

Accepted author manuscript

Link to publication record in Manchester Research Explorer

\section{Citation for published version (APA):}

Bithell, C. (2006). Musical Archaeologists: The Revival and Reconstruction of Polyphonic Masses in Corsica. Ethnomusicology Forum, 15(1), 113-145. https://doi.org/10.1080/17411910600634395

\section{Published in:}

Ethnomusicology Forum

\section{Citing this paper}

Please note that where the full-text provided on Manchester Research Explorer is the Author Accepted Manuscript or Proof version this may differ from the final Published version. If citing, it is advised that you check and use the publisher's definitive version.

\section{General rights}

Copyright and moral rights for the publications made accessible in the Research Explorer are retained by the authors and/or other copyright owners and it is a condition of accessing publications that users recognise and abide by the legal requirements associated with these rights.

\section{Takedown policy}

If you believe that this document breaches copyright please refer to the University of Manchester's Takedown Procedures [http://man.ac.uk/04Y6Bo] or contact uml.scholarlycommunications@manchester.ac.uk providing relevant details, so we can investigate your claim.

\section{OPEN ACCESS}




\title{
Musical Archaeologists: The Revival and Reconstruction of Polyphonic Settings of the Latin Mass in Corsica
}

\author{
Caroline Bithell \\ University of Manchester, UK
}

NOTE: This is a post-print (Author's Accepted Manuscript) for:

Bithell, Caroline, 'Musical Archaeologists: The Revival and Reconstruction of Polyphonic Masses in Corsica.' In The Past in Music, ed. Caroline Bithell special issue of Ethnomusicology Forum, vol. 15/1 (2006): 113-145. DOI: $\underline{10.1080 / 17411910600634395}$

This paper focuses on the revival and reconstruction of polyphonic settings of the Latin Mass in selected villages in Corsica. Many such mass settings, often unique to a single village and preserved only in oral tradition, fell into disuse during the first half of the 20th century for a variety of reasons that are briefly explored. In some cases, however, fragments remained in the memories of surviving singers or on old recordings and these were to provide the seeds for the repertoire's later renaissance. My account of the processes of retrieval, reconstruction and reabsorption of the musical material itself is balanced by an examination of the different motives and ideologies of the various parties involved, together with an exploration of the broader theoretical implications of the enterprise of reclaiming the musical patrimony and, in particular, what it reveals about attitudes towards the past, authenticity, ownership and local identity. In the course of my analysis I draw on a series of metaphors and paradigms from the fields of archaeology and heritage conservation. Ultimately, I argue that the renewed practice of singing the mass in the "old way" should be viewed as an authentic part of the Corsican present.

Keywords: Corsica; Oral Polyphony; The Latin Mass; Musical Reconstruction; Archaeology; The Past; Identity; E Voce di u Cumune.

\section{Introduction: Musical Reconstruction and Archaeological Models}

"It is sometimes surprising how far one can go in reconstructing what no longer survives."

(Redknap 2002, 24) 
There are many churches in Corsica today where, on the main liturgical feast days, for village patron saints' days and for funerals, the mass can be heard sung in Latin by a small group of men in a distinctive three-voice polyphonic style and in a musical setting that varies from one village to the next. The stories behind some of these masses constitute the main subject of this paper. ${ }^{1}$ I focus in particular on three villages in the north of the island - Pioggiola (Pioghjula), Olmi Cappella and Speloncato (Speluncatu, Spiluncatu) ${ }^{2}$ - whose masses have undergone a conscious and relatively formal process of musical reconstruction after lying dormant for a generation or more and have now, 15-20 years on, re-established themselves as an integral part of the contemporary religious life of the villages concerned.

In my engagement with these masses and with the people variously involved in researching, reviving and singing them, I have inevitably been drawn to thoughts about archaeology and the way in which archaeological metaphors, and perhaps methodologies, might be applied to the case. Of the concepts commonly associated with archaeology - decay, abandonment, rediscovery, exhumation, documentation, conservation, restoration, interpretation, reconstruction - many might also be applied to the "relic" of the mass and its treatment by the various protagonists in my story.

At the most obvious level, the archaeological paradigm can serve us by helping to elucidate the nature of the musical material itself. Just as an archaeological site has often been occupied at more than one time in the past and therefore consists of a number of culturally distinct deposits found in the different strata, so a musical

Caroline Bithell (PhD Wales) is Lecturer in Ethnomusicology at the University of Manchester, UK. Drawing on her research into Corsican music, she has published a number of journal articles and book chapters spanning a range of thematic and theoretical areas, including oral traditions of vocal polyphony, the revival and reconstruction of traditional repertoires, the commercialisation and professionalisation of traditional music, music and gender, music and nationalism, and the politics of fieldwork and ethnography. Her book Transported by Song: Corsican Voices from Oral Tradition to World Stage is shortly to appear in Scarecrow Press's series Europea: Ethnomusicologies and Modernities. Correspondence to: Music, Martin Harris Centre for Music and Drama, The University of Manchester, Coupland Street, Manchester M13 9PL, UK. Email: Caroline.Bithell@manchester.ac.uk

1 This paper draws on research carried out in Corsica since 1993 and consolidated by means of a special investigation in the summer of 2002; the work was further updated in the summer of 2004, at which time I also reviewed a draft of the paper with my main informants/contributors. An earlier version of the paper was delivered at the 2003 conference of the British Forum for Ethnomusicology (University of Wales, Bangor). Preliminary thoughts on the way in which archaeological paradigms might be applied to a consideration of some of the Corsican material also informed a presentation given at the 1996 Giving Voice Festival (organised by the Centre for Performance Research, Aberystwyth), which took as its theme "The Archaeology of the Voice".

2 For the sake of consistency and ease of locating the places referred to in the text, I use the standard spellings of place names as found in most maps and guidebooks. Many place names also have alternative spellings that more accurately reflect Corsican pronunciation: these, and other variants sometimes found in publications, disc notes etc., are given in brackets at the first mention. 
heritage is built on layer upon layer of accretions through time. The Corsican churches in which the masses are sung have often struck me as an apt metaphor for the music. An inscription found in the church of Speloncato (Figure 1) will illustrate the point: "Etruscan site dedicated to St. Michel C6th Roman church C11th Facade $1509 \sim$ Baroque choir $1755 \sim$ Bell $1913 \sim$ Restored 1970". To assume that a repertoire came into being as a finished product in its present state is analogous to believing that the earth was created in a day. What might have been created only yesterday is the uppermost layer and it is this that, at surface level, often counts as tradition. While such observations may be self-evident, they have an important bearing on notions of authenticity as alluded to later in my discussion.

Some observations with respect to the possible provenance and evolution of the mass settings are included in the early part of my discussion. My concern here is not, however, to seek to reconstruct a chronology of the musical fabric with fixed dates. We cannot apply radiocarbon dating to past vocal practices of which the main archive is the human memory, and attempts to date aspects of musical style on the basis of developments in the history of western art music are unsatisfactory when faced with a living oral tradition where musical features that are perceived as archaisms by listeners from outside the tradition often still operate as legal tender for those inside the tradition - a point to which I return later in this paper. ${ }^{3}$

Archaeology has, of course, long since moved on from the honest and earthy pleasures of digging up relics as an end in itself. Archaeologists seek to understand, on the basis of both the artefacts they uncover and observations of present-day societies, how culture operates and why cultures change. In the present context, the various groups and individuals engaged in processes of musical revival and reconstruction - who might themselves be seen to be engaging in a type of musical archaeology in the older sense - can be viewed as agents of change, their activities serving as the evidence from which extrapolations might be made as to how change might also have occurred in the past: as an object of my study in their own right, they become links in the chain of musical evolution.

More recently, in the climate of the post-modern crisis of representation that has affected the social sciences in general, proponents of the "new", interpretive and postprocessual archaeologies - drawing on, amongst others, Bourdieu, Geertz and

\footnotetext{
${ }^{3}$ A similar point is made at the Musée de la Corse at Corte (Corti) in connection with techniques associated with the traditional rural lifestyle, where modern techniques happily coexist with those that elsewhere in Europe would be considered out-of-date. "Can we speak here of archaism?" asks
} 
Ricoeur on the one hand and Foucault and Marxist critiques on the other - have transferred their allegiance from the notion of a single, monolithic, unified past, revelatory of an objective "truth", to a series of multiple and fragmented pasts whose meanings are partial, equivocal and subjective (see e.g. Buchli 1995, 183; Thomas 1995, 357). 4 The past and its narratives have become polyphonic. I also invoke the archaeological trope, then, as a tool for interrogating the different notions of, and ways of engaging with, the past that emerge from an examination of the diverse motivations, methodologies and ideologies of the different parties involved in these stories of musical reconstruction.

\section{The Mass in Corsica}

Until the early decades of the 20th century, it would appear that most villages in Corsica possessed their own more or less unique settings of the Latin Mass - both the messa di i vivi or messe des vivants (literally the Mass of the Living, today sung mainly for patron saints' days and the more important liturgical feasts and, in some places, on ordinary Sundays) and the messa di i morti or messe des morts (the Requiem Mass, sung for funerals and All Souls). These masses - mostly for three voices and sung a cappella - were transmitted orally from one generation to the next: they are not preserved in written form. The ordinary village men who formed the équipe or singing ensemble were close friends or members of the same family and would typically sing together as a fixed group for several years, often until one of their number died. As is the case today, they did not undergo any formal musical training in a conventional sense but learnt their craft from their elders. In some cases, the singers are also members of the local confraternità (confraternity or Catholic lay brotherhood) and often the same individuals can be found singing paghjelle in more secular surroundings. 5

When the mass is sung as described above - by a small group of male singers, in polyphony - it is popularly referred to as a messa nustrale (the native or indigenous mass). Because of stylistic similarities with the secular paghjella, it is also referred to

one of the information boards. "No, the Corsicans utilised the techniques that were most suited to their society and to their economy."

4 For an entertaining if sobering tirade against interpretive anthropology and its reification of meaning, together with its presentation of itself as a moral as well as a methodological revolution, see Gellner 1995.

5 The paghjella (pl. paghjelle) is the most popular type of polyphonic song still widely heard in the living tradition. 
as a messa à paghjella (the mass in paghjella style). The inclusivity of this nomenclature, however, belies the fact that mass settings found in different parts of the island vary quite significantly in both form and style. As is the case with the secular paghjella, for which each village has its own versu or musical variant, the greatest degree of similarity can be found between masses of neighbouring villages. Thus the masses found in number of villages in the Castagniccia (the region of the great chestnut forest in east-central Corsica) appear to be derived from the same prototype, while those found in the Balagne (north-west) or in Cap Corse (the peninsula to the northeast) are constructed on a different basis even though they are to some extent related through a similar stylistic treatment. ${ }^{6}$ Most but by no means all of the masses are in the three-part paghjella style that is now recognised as the archetypal Corsican sound. Some are more homophonic, making greater use of parallel movement between the voices; in some pieces, chains of 6-3 chords occur, suggestive of faburden. Examples where such parallel movement is sustained throughout are, however, rare. In other instances where parallel movement is found, it appears in alternation with passages in paghjella style where the bass assumes a more functional role.

Markus Römer's research in the early 1970s into the relationship between these orally transmitted masses and those found in manuscript sources - mainly of Franciscan provenance - surviving on the island revealed surprisingly little correspondence between the two repertoires (Römer 1983). ${ }^{7}$ While a number of cases emerged of isolated items still existing in the oral tradition being clearly derived from material found in manuscript form, these appear as exceptions and the style of the material concerned does not always bear a direct relationship to the characteristic paghjella style. ${ }^{8}$

\footnotetext{
${ }^{6}$ Römer does, however, suggest that a number of settings of the Kyrie from different parts of the island can be seen to be derived from the Kyrie of the Gregorian Requiem Mass. In the 1970s Römer recorded some examples sung in three parts, some in two and some sung solo. Despite the fact that these Kyries often sound like quite different pieces, the correspondence becomes more evident when transcriptions are compared. (See Römer 1983, 220-23 and 1996, 48-49.)

7 Large quantities of material records were, however, destroyed during the wars with the Saracens, the later struggles with Pisa and Genoa and finally during the years of the French Revolution: thus concrete evidence of earlier practices is limited.

${ }^{8}$ An interesting example is provided by one of the two Dies Irae sequences sung in Sartène (Sartè) and referred to by the singers there as the "Dies Irae dei frati" ("Dies Irae of the brothers [monks]"). Römer notes that this is derived from the Requiem of P. Franco found in the manuscript Bastia BPFC 01.6.15, originally from Sartène, as well as in a second manuscript from the convent of Marcasso. The same sequence is sung in Pozzo-di-Brando (Pozzu-di-Brandu) in Cap Corse in an arrangement for two voices. (See Römer 1983, 266-7.) More recently, Michel Foussard (medievalist, musicologist and Chargé de Mission pour le Patrimoine Musical for the French Ministry of Culture) has undertaken a census of masses found in Corsica in printed or manuscript form, using a specially designed computer programme as an aid to melodic comparison. Comparisons were also made with mass settings from the Conté de Nice, Piemont and Liguria. Preliminary findings suggested two parallel trends: on the
} 
The two best known masses - which have survived into the present without a break in their transmission and which exemplify the paghjella style - are those of Sermano (Sermanu) and Rusio (Rusiu) in the Castagniccia, one of the last strongholds of paghjella singing in general. The masses share a number of features with the secular paghjella as follows: (i) the voice entries are staggered and occur in the same order, and the individual voices - secunda (seconda, siconda), bassu and terza have similar functions (although the terza sometimes moves in parallel thirds above the secunda rather than articulating around the fifth degree of the scale, which in the secular paghjella functions as a type of pedal note); (ii) the range of the secunda is normally restricted to a fifth and movement is predominantly by step with occasional leaps of a third; (iii) the secunda and terza voices employ characteristic melismatic patterns, leading in many instances to the type of textual deformation found in the secular paghjella (albeit of a less radical nature); (iv) while intervals are for the most part untempered, the pieces end with a characteristic tierce de Picardie type resolution; (v) the pieces do not conform to a strict meter.

Knowledge of the Sermano and Rusio masses outside their immediate locality has been greatly facilitated by recordings released on the Adès, Auvidis and Consul labels. The first recording of the Rusio mass (later to be released on Adès and sold for the benefit of the village church) was made in 1959 by Corsican musician and collector Félix Quilici. ${ }^{9}$ Quilici had initially "discovered" Rusio through the singer Charles (Carlu) Rocchi (one of the singers to be featured on the recording), who sang in the choir A Cirnea, made up of Corsican expatriates in Paris and directed by Quilici himself. For Quilici, the Rusio mass was a revelation, appearing as a living relic of an ancient and noble past. His reaction on first hearing the music is recorded in an article in Kyrn magazine: "What I was hearing, mixed with forms closer to us, was, coming from the furthermost centuries, the first stammerings of polyphony." 10 The article goes on to comment: "The archaic structures of the music, like the parallel movement of fourths, fifths and octaves, for example, the timbres of the voices, its

one hand, a history of musical exchange between Corsica, Piemont and Liguria and, on the other, a significant number of apparently "autonomous" compositions/traditions.

${ }^{9}$ Quilici trained as a professional violinist and viola player and enjoyed a distinguished career as soloist with the Orchestre National de la Radiodiffusion (later the Orchestre National de France) in Paris. He also held a degree in History of Art and Musicology from the Sorbonne. Between 1948 and 1963, he undertook a series of official recording expeditions to his home island, the first (1948) as part of a research team sponsored by the Musée National des Arts et Traditions Populaires, the second (1949) on behalf of Radiodiffusion Française and the third (early 1960s) as Attaché de Recherche for the Centre National de la Recherche Scientifique.

10 All translations from non-English sources are my own. 
emission, the interpretation, all of that indicates the direction of the Orient, and an epoch significantly earlier than Gregorian chant" (Anon. 1976, 51).11

Young singers from all over the island have since learnt these masses either directly from the recordings or via the network of scole di cantu (singing schools) some even make the pilgrimage to the villages themselves to learn directly from local singers - with the result that the Rusio mass in particular can now be heard all over Corsica and has come to be viewed, effectively, as the Corsican mass. Rusio and Sermano are, however, exceptions to the rule. Overall, the perpetuation of the indigenous mass tradition in the 20th century was severely compromised. Römer's retrospective survey (1983) based on fieldwork carried out in 1974-5 reveals an alarming rate of decay. The two world wars in which many singers perished had a particularly devastating effect. In many cases, there was simply no-one left in the village with sufficient knowledge of the repertoire to be able to ensure its continuation. As a result, the old local masses were now increasingly replaced by either the Gregorian Missa de Angelis (referred to locally as the Messe des Anges) or what singers dub "the Dumont mass". ${ }^{12}$ At the same time a number of the priests, not all of whom had enjoyed easy relations with the often independently minded male équipes, seized the opportunity to establish more manageable women's choirs who were taught to sing a comparatively sanitised repertoire of French canticles, accompanied by the harmonium. ${ }^{13}$ One singer refers mischievously to these women's choirs as "the priest's revenge". Meanwhile, Römer has observed that these choirs were part of the process whereby women came to play a more significant role in social terms (pers. comm. July 1994).

The role of those singers who continued to sing the mass in the old way was further eroded after the Second Vatican Council (1962-1965) as Latin found itself

\footnotetext{
11 For detailed analyses of the Rusio material, see Chailley 1982 and Römer 1983. Notwithstanding the "ancient" echoes heard by Quilici and others, Römer concludes that the material in the form in which it exists today, in which early Medieval features are combined with procedures popular in the Renaissance period, is likely to date from no earlier than the $16^{\text {th }}$ century. This assessment is unpopular with many Corsicans who believe the material to be far older.

12 For many, these settings came to be viewed as "traditional". Max Vuillamier, prieur (prior) of the confraternità in the village of Lumio (Lumiu), for example, says that "for the old people of the village, the village mass was, to all intents and purposes, the mass of Dumont" (interview July 2002).

Dumont's Cinque Messes en Plain-chant of 1669 were reissued as Messes Royales in 1701; they have since undergone regular reprints and are sung in many French churches.

13 Annie Goffre comments that even before this stage polyphonic practices in a number of places had been compromised by the introduction of organs - often gifts made by local families who had made their fortunes abroad (CEF-MNATP \& EVC 1992, 76). In Cap Corse, for example, there was a wellestablished tradition of emigration to parts of South America and the Antilles. On their return to the island of their birth, these families not only built themselves grand houses but also poured money into
} 
displaced in favour of a new liturgy in the so-called vernacular. In Corsica this meant the official national language, French, which for many Corsicans is a foreign language, and not the indigenous language, Corsican, which itself is far closer to Latin - a circumstance that adds greater weight and reason to the enthusiasm for reinstating the Latin Mass. ${ }^{14}$ A further dimension to Vatican II with its concern for demystification and greater inclusivity was the move towards supposedly more accessible musical material that could be sung by the whole congregation. Paul Félix Nasica of the group I Chjami Aghjalesi - who sang in the church choir in Bastia as a boy in the 1960s - recalls how, in the space of a year, the church switched from Latin to French, the new French liturgy being accompanied by adaptations of "popular" songs such as "When the Saints go Marching in" (interview July 2004). Jacques Gregori, writing in an issue of Kyrn magazine, refers to 1962 as "the year of disgrace": "After this date, the official language of the Republic, One and Indivisible, transformed the mass, which up until then had been a Baroque opera, into burlesque tatters. At once the churches ceased to be schools of music " (Gregori 1991, 41). The standard fare in many Corsican churches today differs little from what can be heard in other parts of France - at best, Gregorian-sounding melodies for the ordinary of the mass, sung by the whole congregation, with a female choir singing harmonised hymns and canticles in French for the Communion etc.; otherwise somewhat bland (and distinctly unmodal) settings of the "modern" French liturgy, interspersed with melodies that sound suspiciously like the afore-mentioned "When the Saints", "Michael Row the Boat Ashore" or "Amazing Grace".

As some singers in Corsica understand the situation, however, the proceedings of Vatican II did not advocate the complete abolition of the Latin or Tridentine Mass. To some extent, the move away from the latter by individual priests is viewed as a matter of local and national politics as much as ecclesiastical ordinance. The part played by individual priests in encouraging the continued practice of the old polyphonic masses certainly appears to have been of crucial importance in those villages where the tradition was maintained. Elsewhere, I have encountered stories of singers who had sung the mass as young men in the 1920s and

\footnotetext{
their local churches. It is significant that the tiny village churches of Sermano and Rusio do not have organs.

${ }^{14}$ The texts of the mass have been translated into Corsican, most notably by the Abbé Guidicelli in the southern capital of Ajaccio and by Canon Alberti in the hamlet of Moncale (U Mucale, Mugale) in the Balagne, and I have on occasion heard the mass celebrated in Corsican or in a mixture of Latin, Corsican and French. The majority of those involved in reviving the singing of the mass in the "old" way, however, adhere to the view that the proper language for the mass is Latin. Meanwhile, the Corsican language itself was once described to me as "really just a modern form of Latin".
} 
1930s but had to wait until they were in their seventies before they had the opportunity to sing it again. There were, in actual fact, other masses apart from Sermano and Rusio that continued to be sung until as late as the 1960s and in some cases into the 1970s, but without receiving any outside attention or promotion. ${ }^{15}$ Even in these cases, however, the situation was by the 1980s at best tenuous, with the accumulated knowledge of generations often residing in the memory of a sole surviving singer. ${ }^{16}$

\section{The Riacquistu}

One of the ingredients of Corsica's cultural revival or riacquistu, fuelled in part by the separatist movement from the 1970s onwards, was a renewed interest on the part of young people in all aspects of their heritage as they sought to reconnect with their Corsican identity and reclaim their patrimoine. Lowenthal $(1985,86)$ comments on the way in which revivals are often informed by the discrediting of an immediate past and the idolisation of a more remote past. In this case, the rejection of a more recent "French" past (now seen by many as alien or at best a diversion) fed into the impulse to return to a more distant yet more recognisable and "authentic" Corsican past, and this in turn combined with a broader movement (growing out of the ethos of the 1960s) to return to a more local and communal frame of reference. A wealth of cultural associations sprang up, largely at grassroots level, motivated by a desire to recuperate what remained of the local heritage and to return to the "authentic" values of "traditional" life. ${ }^{17}$ Many of these associations were originally formed with a concrete focus such as the restoration of the village church or the renovation of a disused organ. They then turned their attentions to the revitalisation of patron saints' days, the reinauguration of the confraternities and, increasingly, the recovery of halfforgotten musical repertoires. ${ }^{18}$

15 Some had also been recorded by Quilici - e.g. Piedicorte (Piedicorti) in 1964 - but remained to all intents and purposes locked away in archives. One of the ironies of the case was that, because of the conditions governing the collecting missions, people in the villages where recordings were made did not usually have access to the recordings themselves.

16 One of the maps in Römer's study, representing a survey of the situation in 1974/75, indicates a total of 33 villages where a single active singer remained (cf Römer 1983, Tafel VIII, facing p. 296).

${ }^{17}$ Associations, constituted in accordance with legislation dating from 1 July 1901, are a prominent feature of French life. By 2004 Corsica possessed a total of almost 20,000 associations (one for every thirteen inhabitants), with almost half the population being involved in some way with the activities of an association.

${ }^{18}$ Immediately prior to the French Revolution Corsica had c. 200 active confraternities, the greater proportion of which apparently continued to function despite the interdiction of 1792. In the 20th 
At the same time, polyphonic singing was experiencing a spectacular renaissance, due not only to its revalorisation in Corsica itself - the paghjella having been elevated to iconic status, in the context of the riacquistu, as an expression of the Corsican "soul" - but also to renewed outside academic interest. ${ }^{19}$ For some this new commitment to polyphony was naturally expressed in an urge to rescue lost polyphonies. Singers now became musical archaeologists, turning every stone in the collective musical memory in an attempt to uncover ever more forgotten fragments of the cultural heritage. In some instances, interest on the part of people with the necessary musical or academic expertise came together with the desire to resurrect local repertoires and rituals that fuelled the cultural associations. Local settings of the mass, which had often been intrinsic to village identity in the past and for which there already existed a well-defined context for their reintegration into the life of the local community, were ideal focal points.

In addition to the lone singers remaining in some villages, there were other people still alive who retained a latent knowledge of mass settings that were no longer sung, including priests, sacristans and altar boys who had never sung the mass themselves but had been present on hundreds of occasions when it had been sung and so had it imprinted on their memories in a way that could be reactivated at a later date. These people were to serve as vital witnesses and, in some cases, direct sources for those who were now showing an interest in reviving the lost repertoires. They were joined by others who had sung the mass as young men and were now returning to Corsica for their retirement years after a working life on the Continent. For the latter, a sense of continuity with the past was particularly important and their urge to recover the Corsica of their youth, kept fondly alive in their memories combined with their newly acquired leisure time - often prompted them to assume a role at the forefront of moves to reinstate semi-forgotten or abandoned practices.

\section{The Process of Reconstruction}

One of the more prominent players in the riacquistu was the association E Voce di $\mathrm{u}$ Cumune (EVC). Founded in 1978, the association was based at the Balagne village of

century, however, they entered a period of unprecedented decline. Those that survived into the 1960s were further destabilised by the fallout from Vatican II; according to one estimate, by the 1970s only 10 remained active to any meaningful degree. In the 1980s, however, this process was reversed and by 2000 around 50 had been reformed.

${ }^{19}$ For a discussion of the academic fascination with oral traditions of polyphonic singing in Europe in general, including comment on trends in Corsica itself, see Goffre 1993. 
Pigna, which had become home to a group of artists, artisans and cultural movers from different parts of the island and whose Casa Musicale (established in 1985) continues to provide a focal point for the association's musical enterprises. ${ }^{20}$ Members of EVC - sensing that the masses of Rusio and Sermano represented only the tip of a polyphonic iceberg and convinced that the Castagniccia was not the only region of Corsica to have had a strong polyphonic tradition in the past - began to take an interest in the vestiges of polyphonic practices remaining in the Balagne. ${ }^{21}$ In the late 1980s, they entered into a joint project with Annie Goffre of the Musée National des Arts et Traditions Populaires (MNATP) in Paris to pursue research into traditional music in selected villages and, more specifically, to work with local singers to exhume and reconstitute abandoned liturgical repertoires. The publication Contributions aux Recherches sur le Chant Corse 1: Polyphonies Vocales et Orgue (CEFMNATP \& EVC 1992), republished as Polyphonies Corses: L'Orgue et la Voix (Acquaviva et al 1996), records the methodology, progress and results of their work in the villages of Moncale, Pioggiola, Olmi Cappella and Speloncato. 22

The working method of EVC involves recording whatever fragments remain in the memory of "survivors", together with indications as to how the three voices fitted together. At the most basic level, this might mean the main melody line or secunda, plus an indication of the points at which the other two voices, bassu (a lower voice) and terza (a higher voice), would have entered and general impressions as to whether the voice would have proceeded by rising or falling. All of this information is notated in a type of tablature that EVC has devised for the purpose. The voices which are either missing completely or represented only by the barest outline are

20 The performance group A Cumpagnia was formed at the same time as EVC in order to "put into voice" the results of the association's research, while the Academia d'i Vagabondi was designed to publish it. Among the most prominent long-term members of EVC are Toni and Nicole Casalonga and Nando Acquaviva. Toni Casalonga is a multi-talented artist (sculptor, painter, engraver) who has also occupied key positions in insular politics, including serving as President of the Conseil Économique, Social et Culturel de la Corse. Nicole Casalonga is a singer and organist (originally from southern Corsica), who continues to pursue her own investigations in the field. Nando Acquaviva, in addition to his musical activities, is proprietor of the main supermarket in nearby Île Rousse. All three teach traditional music at Pigna's Saturday music school. Nicole Casalonga and Nando Acquaviva hold the Certificate of Aptitude in the Teaching of Traditional Musics introduced as part of the promotion of traditional and regional forms of expression by Mitterrand's government in the 1980s.

21 The Balagne had, up to this point, received relatively little attention. Römer reports that he found very few traces of local liturgical repertoires in the Balagne in the course of his own research in the 1970s (pers. comm., various dates). EVC's musical interest was initially a by-product of Toni Casalonga's involvement in restoration work in churches in the area. It was this that first brought him into contact with members of the village associations; the conversation later turned to music (Nicole Casalonga, interview July 2004).

22 Separate chapters are contributed by members of EVC on the one hand and Annie Goffre on the other. A recapitulation or evaluation of the musicological analysis undertaken by Goffre lies beyond the objectives of the present study. 
reconstituted in a manner that relies in part on familiarity with examples of more complete repertoires and with the principles generally characteristic of the indigenous musical language. ${ }^{23}$ The reconstituted piece is then performed for the inhabitants of the village in order for them to assess how closely this corresponds with their memory of the original and to choose what to keep and what to reject. It is at this point that latent memories can be further stimulated and listeners who would have been able to contribute little if approached cold are able to make such comments as: "Yes, it started right but the terza should go higher at such-and-such a point."

This process interestingly harnesses some of the peculiarities of the nature of memory. As researchers elsewhere have found, songs are located not only in the musical memory but also in the muscles and the rhythm of the blood. Reliving the ritual itself can therefore help to relocate the songs by stimulating memories and responses in both the brain and the body that are associated with it - a process that is often far more effective than relying on the predominantly left-brain activity involved in simply trying to think about something. Similarly, a reminder of a fragment of a song can sometimes bring the whole thing flooding back. I was present on one occasion at a rehearsal in the village of Speloncato where the organist, Elisabeth Pardon, wanted me to hear two different versions of the Absolution, the Libera Me, that had been sung in the village in the past. The two oldest singers insisted that there was only one version; if there had once been a second one then they certainly hadn't ever sung it themselves. When Pardon tentatively began singing it, however, they happily took over but afterwards remained unconvinced that this was any different from the other Libera Me: they were simply both the Libera $M e$. This ability to give evidence which one is, at a conscious level, unaware one has knowledge of is one of the mechanisms that can be exploited by those conducting research into "lost" or forgotten repertoires.

For its graphic transcriptions EVC has refined a system of figured notation which has the advantage, compared to one in which notes are placed on a stave, of not fixing the note absolutely in terms of either pitch or duration. The degrees of the scale corresponding to the dorian mode are represented by the Arabic numerals 1 to 8 (with 9 and $X$ being used for the second and third degrees of the secunda's range

\footnotetext{
23 Toni Casalonga comments that in cases where the secunda and bassu voices have been transmitted, the terza doesn't have many choices: it is more or less obvious where it should be placed. If, on the other hand, it is the secunda and terza that have been transmitted then there are more possibilities for the bassu (pers. comm. April 1995).
} 
when used by the bassu). Reversed or combined numerals are used to indicate modal variants of the same degree of the scale (e.g. minor, middle and major third, represented by a normal 3, a reversed 3 fused with a normal 3, and a reversed 3 respectively). The complete scale includes three notes which do not feature in the equal-tempered scale, namely the middle 3rd, middle 6th (a perfect 4 th away from the middle $3 \mathrm{rd}$ ) and middle 7 th. A series of diacritic symbols, baptised $i$ fiori ("flowers"), is used to indicate a variety of further features of performance, including melismas, glissandi, dynamics, respiration, closed or open mouth etc. Any transcription produced using this method might relate either to a particular performance, with the singer of each voice identified, or to a reconstruction, in which case the origins of the given and reconstructed voices are noted. An example of one of EVC's transcriptions is given in Figure 2. 24

\section{Three Cases Studies}

I turn now to the case of three of the villages whose masses were reconstituted in this way. ${ }^{25}$ Speloncato is located high up in the hinterland of the Balagne, where it clings to a rocky outcrop from which many of its houses seem to grow organically (Figure 3). Pioggiola and Olmi Cappella - relatively close neighbours by Corsican standards, situated in the region of the Giunssani (Ghjunssani, Ghjunsani, Giussani) - are reached by a tortuous and precipitous mountain road that leads up from Speloncato over the Bocca (Col) di a Battaglia: at 1,000 metres above sea level, Pioggiola counts among the highest villages in Corsica. I have visited each of these villages on numerous occasions in the course of my association with the island and so have been able to witness at first hand the progress of the reconstructed masses in the years following the involvement of the EVC/MNATP team.

Pioggiola's mass had continued to be sung until the mid 1930s when the last cantor, who had sung the principal voice (secunda), had died. Since he had not taught his part to anyone else, the remaining members of the ensemble simply disbanded. Soon after, the women took over the role of singing the mass, but what they sang - as in many other villages at this time - was either "the Dumont mass" or the Messe des

\footnotetext{
24 A full set of transcriptions, together with a more elaborate explanation of the system itself, can be found in CEF-MNATP \& EVC 1992 and Acquaviva et al 1996.

${ }^{25}$ Moncale, near Calenzana (Calinzana), was the first village with which members of EVC and Goffre became involved. For the purposes of the present discussion I am concerned with the other three villages that feature in CEF-MNATP/EVC's 1992 account.
} 
Anges. 26 In 1981, however, Santu Massiani, the local schoolmaster, who together with two others had already begun the process of reviving the practice of traditional liturgical music in the village, invited members of EVC to meet two older men who still retained parts of the mass in their memories - memories which Massiani always refers to as "faithful". These two, Sestu Carboni and Matteu Colombani, had recently returned to the village for their retirement and had begun to recall the secunda lines of the Ordinary of the mass as they had heard it in their youth as choirboys. Nando Acquaviva of EVC helped them reconstruct the other two voices, choosing between the various possibilities that presented themselves on the basis of what he already knew of other indigenous liturgical repertoires and by listening to examples of secular polyphonic songs that were sung to him by three sisters living in the village (the eldest was 80 years old and they had not sung for some considerable time). ${ }^{27}$ The oldest inhabitants were looked to for confirmation and adjustments were made on the basis of their responses. The arrangement that finally emerged was then relearnt by the present singers, who have now been singing the reconstituted mass for almost 20 years and see it quite firmly as their traditional mass. They are confident, says Massiani, that the mass as they sing it today is $90 \%$ true to what it was before the break in transmission. The Kyrie is not exactly right, but it is as close as they could get it; in the case of the Agnus Dei they also had to make compromises but the reconstructed version worked well and has now become their own (interviews June 2002 and July 2004).

It should be stressed that Acquaviva's relationship with Pioggiola was by no means that of a detached scientist. At every stage of the reconstruction he worked closely with the local singers in a process of intense engagement and collaboration. It was, observes fellow EVC member Nicole Casalonga, "almost a daily preoccupation", the interaction operating as "a veritable crucible" (interview July 2004). While the mass was still being stabilised, Acquaviva sang with the local équipe; and for the Feast of the Assumption (15 August) he would be joined by Nicole

\footnotetext{
26 The Absolution of the Requiem Mass (the Libera Me) was ultimately the only song from the older tradition to survive in living practice in Pioggiola and it is this - in Santu Massiani's words - that provides the direct link with the present. When the village was without an équipe to sing the mass, the Libera Me would be sung by the whole congregation (Massiani interview July 2004).

27 This assumes a close structural relationship between items from the sacred and secular repertoires attested in the same location that is generally accepted but would bear further scrutiny. The sisters in question had been taught to sing in polyphony by their father, who had no sons, and represent a celebrated exception to the norm of polyphonic singing as a male prerogative.
} 
Casalonga and Antoine Massoni. ${ }^{28}$ "With them," says Casalonga, "we experienced an adventure that marked us deeply, both musically and socially."

In the neighbouring village of Olmi Cappella (Figure 4), a return to the liturgical traditions of the past had already been set in motion two or three years prior to EVC's involvement by Elisabeth Pardon from the nearby village of Belgodère (Belgodè), who had begun to play the recently restored organ, and Pierre Oberti from Muro (Muru), president of the association Renaissance de L'Orgue Corse. ${ }^{29}$ The village mass had gradually declined in the decades following the First World War, even if the messe des morts had continued to be sung for longer than the messe des vivants after the introduction of a women's choir. ${ }^{30}$ The old singers had apparently taken their role as guardians of the repertoire particularly seriously. Any prospective singer wishing to join their ranks had to be judged to possess the right spirit: simply being a good singer was not necessarily a sufficient qualification. The process of transmission had, therefore, not always been smooth. One of the old singers was still alive, however: Ceccu Saladini, born in 1912. In the case of the Agnus Dei (Figure 2), he remembered both the secunda and terza lines and the beginning of the bassu line, which in this case had been the first voice to enter. This is an exception to the usual order of entry of the voices, but is a peculiarity shared by the Agnus Dei of Urtaca and by a paghjella recorded by Félix Quilici in the village of Castiglione in 1948 (ATP 49.1.56: the piece is entered in the collection as "Torna torna a quella sponda" but is now generally referred to as the versu di Castiglione). Informed by these two examples, Nando Acquaviva completed the arrangement, trying out the different possibilities for Saladini's approval. Other parts of the mass were more fragmentary and a greater degree of reconstruction was required; in this case Pardon and Oberti also worked directly with Ceccu Saladini. In the estimation of the équipe who sang the revived mass in the 1990s (Figure 5), however, the reconstruction needed was minimal and they saw themselves as having learnt "from

\footnotetext{
${ }^{28}$ In his capacity as organ tuner, Massoni further contributed to consolidating EVC's relationship with the village.

${ }^{29}$ Elisabeth Pardon, originally from the Continent, has been installed in Corsica with her sculptor husband for many years and has devoted considerable energy to nurturing the cultural heritage of her corner of the Balagne. One of her most recent initiatives has been to design and lead - under the auspices of the Association Saladini de Speloncato - highly entertaining and instructive tours of the island's churches, at each stop recounting the history of the church, its art and its confraternity, as well as playing on its organ. Pierre Oberti, who in addition to his involvement with the renaissance of the Corsican organ has served for many years as mayor of his home village of Muro, is a science lecturer at the University of Corsica.

${ }^{30}$ In this case "the last fragment of polyphonic expression" was the Lode of St. Roch, still sung in two parts in the 1970s by Ceccu Saladini and Pierre-Jean Squarcioni (Santu Massiani, interview July 2004).
} 
the old singers". In Olmi Cappella, as elsewhere, I was told stories of how the old people of the village were moved to tears when they finally heard the mass sung again and of their astonishment at how closely the resurrected version resembled that which they had known in their youth: it was as if the dead had returned. ${ }^{31}$

Speloncato's mass had been recorded by Félix Quilici in 1949; the recording was, however, not easily accessible until copies of the Quilici collections were deposited at the island's own Phonothèque (part of the Musée de la Corse at Corte) and by then the sound had suffered distortion. In 1986 the Reverend Squarcioni (at that time the priest of several villages in the Balagne) and Jean-Dominique Poli (a university lecturer and one of the present singers) made a recording of the secunda line of both the messe des vivants and the messe des morts, sung by the former canon, Michel Colombani, and his brother Antoine, former cantor and prieur of the village confraternità. ${ }^{32}$ Making the recording was apparently surprisingly straightforward: the brothers simply sang through both masses. As at Olmi Cappella, Nando Acquaviva and his co-workers from EVC were not the only ones to be involved in the reconstruction initiative. Elisabeth Pardon - the organist already encountered in the story of Olmi Cappella - had been asked by Squarcioni to take on the role of organist at Speloncato and had agreed, with the condition that a concerted effort should be made to revive the mass. She then began working on the Colombani recordings independently of Acquaviva, initially collaborating with Pierre Oberti (also encountered above).

Unfortunately the Colombani brothers died not long after their recording had been made and so the reconstructed pieces could not be tested for their approval. Another important informant, however, was Martin Ambrosini, who has acted as sacristan since his return to the village in 1977 after 30 years in Lyon. He had never sung the mass himself prior to his departure but had, in his own words, "more or less lived in the church" as a child and his memory was jogged by the recording of the Colombani brothers. ${ }^{33}$ Annie Goffre of the MNATP made further recordings with

\footnotetext{
31 The response to the rebirth of the old polyphonic masses has, however, not always been unequivocally positive. Singers in one village reported that some local people had been wary at first of the reconstruction initiative, suspecting the singers of nationalist tendencies at a time when it was mainly "the nationalists" who were showing an interest in the "old ways" and in particular in the indigenous style of polyphonic singing. When they saw how much interest was aroused, however, they were reassured.

32 It is again noteworthy that interest in the abandoned liturgical repertoires was rekindled by the inauguration of the restored organ, an event that brought the whole community together and brought the past to life again, with the organ functioning as an important symbolic focus of village identity.

${ }^{33}$ Ambrosini is not generally viewed as "a singer" as such but is credited with possessing an excellent memory.
} 
Ambrosini, while Pardon also worked independently with Ambrosini, Marie Quilici and other older singers in the village, some of whom remembered things slightly differently from how they had been sung by the Colombani brothers. ${ }^{34}$ Pardon also had access to the Quilici recording, which included other material apart from the mass; Ambrosini likewise remembered additional material, such as the Tantum Ergo and other liturgical hymns. In this case it was Pardon who worked with the village singers, painstakingly re-teaching the material to anyone (male or female) who wished to be involved while adapting to their individual capabilities and temperaments. A significant contribution was also made by Santu Massiani, who would regularly travel down from Pioggiola to attend the weekly rehearsals. The mass was sung again for the first time in 1991 but with the secunda line only. Pardon stresses the collective nature of the process of reharmonisation that followed: they would begin by listening together to the cassettes; she might subsequently propose a particular harmonisation but it would then be "transformed" by the group until an equilibrium was reached (interview July 2004).

Meanwhile, Nando Acquaviva continued to work on his own reharmonisation with other members of EVC. In Speloncato, then, the research did not lead to one composite reconstruction but to two separate arrangements, one by Acquaviva and the other by Pardon. Pardon's efforts have contributed significantly to what is now sung in the village by members of the revived confraternity; her work has not, however, benefited from formal documentation.

\section{Theory, Method and Ownership}

I turn now to a more theoretical examination of the different approaches to this work adopted by some of the key players. In the case of EVC, the extended and multifaceted process of collaboration and reconstitution as described above results in a final score, approved and accepted by the local singers, which then forms the basis for future performances in an essentially prescriptive manner - even if this does not preclude the possibility of future adjustments as the material continues to settle. As noted earlier, the notation system itself has been designed in such a way as to allow for the small degree of improvisation or variation which is always present in the living tradition, enabling the piece to unfold in performance as organically as

\footnotetext{
${ }^{34}$ Interestingly, Marie Quilici reports that, in the past, while the men sang the mass at the front of the church, some of the women who knew the melodies would join in quietly from their place in the
} 
possible. For this reason, Toni Casalonga refers to the written page as "mezu-scrittu" or "semi-written" (CEF-MNATP \& EVC 1992, 56.) Annie Goffre (representing the MNATP), on the other hand, works according to the more conventional ethnographic method of recording only what is given by the informant. Any written score that results is a descriptive transcription of the recorded material, translated as faithfully as possible into musical notation. 35

This essential difference in methodology is clearly related to the intended use to which the material is to be put. The primary purpose of the MNATP as a museum is to collect and document cultural artefacts and associated practices and to provide an archive for their safekeeping, conservation and controlled consultation. The researcher is a relatively objective and academic outside observer and there is no assumption of an ongoing active involvement with the future development of the material in its original location: the recordings and associated transcriptions have the status of scientific documents, to be analysed for what they can reveal about the historical past as well as providing a record of the present state of the material. This approach adheres to the principles of basic conservation (as embraced by William Morris and discussed in Butt 2002, 197), which aims to ensure that rescued fragments do not deteriorate further. In the case of music, however, fragments preserved in this way are of limited practical use. If the music is to be heard again, the missing pieces must somehow be restored. EVC, by contrast, do not see themselves as detached ethnographers. They are certainly concerned with the past - illustrating Corsica's part in the grand movements of the Baroque, for instance - but also with the future. For them, it is important that the results of their work should be fed back into the living tradition. They might therefore be seen to be operating in the spirit of experimental archaeology with its attempt to recreate lost production processes. They are also entering into the realm of restoration, with its share of speculation and testing of hypotheses. The working model that results is given back to the local community where it can be further refined in the forge of a living oral tradition. ${ }^{36}$

Reconstructions, like transplants, can be accepted or rejected. An assessment of the success of such projects in terms of their stated objective of aiding the reinstatement of local traditions must therefore involve an examination of the extent

congregation (Pardon interview July 2004).

35 Annie Goffre's transcriptions (as reproduced in CEF-MNATP \& EVC 1992 and Acquaviva et al 1996) use conventional musical notation.

${ }^{36}$ Nicole Casalonga also stresses EVC's interest in the process of transmission itself, from a pedagogical point of view (interview July 2004). 
to which the reworkings have been reabsorbed into the fabric of village life and continue to be moulded to the point where they comply with local singers' perceptions of what is traditional. In the most successful cases, researchers have worked closely with local singers who were already eager to revive their repertoire and welcomed the additional help offered. The village singers have then continued to sing their revitalised masses on the appropriate occasions, with the material being accepted by all involved as an authentic continuation of the tradition. A decade later the mass is firmly re-established as "the mass of [such-and-such village]" and details as to which elements were reconstituted or added and by whom have, for the most part, paled into insignificance.

Once the mass has been reinstated, the role of those who have helped with its reconstruction is theoretically over, at least as far as the village is concerned. For the researcher-restorer, however, letting go is not always easy. An anecdote recounted by the singers of Pioggiola and also by members of EVC neatly illustrates the tension between, on the one hand, the power of tradition and the ease with which it reestablishes itself and, on the other, the sense of continuing parental and professional responsibility on the part of the outside collaborator (who has also, by now, become a friend). Twelve years after the original reconstruction, Nando Acquaviva wanted to make an alteration to a chord progression in the Kyrie of Pioggiola. When the modified version was sung by members of EVC in Pigna, however, one of the village singers, shepherd Antoine-Jean Luiggi - who on this occasion was in the audience was outraged at this departure from the sound he had grown accustomed to. "No, no, no! That's not the traditional mass!" he objected, to which Acquaviva replied: "Listen! The traditional mass is my tradition. I can change whatever I like! ... I can say, the first time I was mistaken: it should be done like this." "Of course, AntoineJean is right," he said later, "it is his mass - but I would so much have liked to make one small improvement" (CEF-MNATP \& EVC 1992, 94).

To complicate matters further, EVC have released their own interpretations of some of the reconstructions on recordings. A disc entitled Missa Corsica in Monticellu (A Cumpagnia, 1994) raised a number of interesting issues. What the disc presents is not a complete mass from one village - the only connection with the village of Monticello (Monticellu, Munticellu) as featured in the title is that the recording session took place in the confrérie church of that village and its organ features on the recording - but a patchwork of movements from different villages in which members of the group had been involved in musical reconstruction projects. This is confusing, 
even if it is not deliberately misleading. Part of the difficulty in this case is due to the way in which the recording has been presented - by the recording company as much as by the group, who were themselves unhappy with the title, for example. According to Nicole Casalonga, A Cumpagnia conceived of the recording in part as a demonstration of their ideas regarding the possible interaction between organ and voices, and as an illustration of work-in-progress insofar as it provides a record of the point reached by the group in terms of research, performance and methodology. She describes the disc as "a kind of acoustic photograph" of the group on that day, as a way of "fixing the work" and documenting "the current state of play", and as "an aid to reflection"; it was not the kind of disc that was meant as a springboard for concerts and tours (interviews November 1994 and July 2004). The outcome, however, in the form of a recording that, by the nature of the medium, remains as a more permanent record will clearly hold different meanings for different listeners, while the disc itself can serve as the means by which other singers learn the material and subsequently reproduce it in their own performances.

A preliminary airing of some of the liturgical material with which EVC was engaged had been given on the earlier disc Corsica: Chant Polyphoniques (1987). In this case the liner notes - written by Marcel Pérès, who acted as musical director - spelt out the group's ideology more explicitly:

This is not an ethnological recording, but the work of Corsican artists ... They are the depositories of a tradition, but not in a passive manner. They are constantly seeking, comparing archive recordings, working in the field, collecting the relics that remain in the memory of the old ... and, above all, never regarding their patrimony as some lifeless object in an ethnological museum, but as a material that is rich enough, alive enough to continue to exist through evolving means of formal expression. ... They have grasped the paradox that makes it possible for a tradition to continue to exist: it must be the source of creation.

(Pérès 1987)

\section{Approaches to the Past}

One significant way in which music differs from the material past is that it can more easily be reproduced and changed in the process. It can be transported from its 
original site on a tape or minidisc, or simply in the memory, without a license and reconstructed elsewhere without the need for planning permission or capital investment. An interesting case in the present context is that of the reconstructed Agnus Dei of Olmi Cappella, which has struck a particular chord with others who have encountered it and can now be found on numerous CDs (not always clearly identified in the liner notes), sung by a variety of groups whose own connections with the village are often tenuous at best, although direct contacts do exist in some cases. In recent years I have also heard this same Agnus Dei sung as part of the mass in a number of churches in different parts of the island. The first commercial CD on which the piece was included was in fact EVC's Corsica: Chant Polyphoniques (1987), with Santu Massiani himself singing the bassu voice. Some subsequent recordings have involved singers who have been associated with EVC. The piece has also been taught at A Filetta's scola di cantu, based at nearby Lumio, and is featured on the group's 1992 disc, Ab Eternu. The extent to which these interpretations might be seen to differ from my own recordings made in the village itself is variable. In respect of one arrangement by the group Caramusa as featured on their 1990 disc, Canti $e$ Musica Tradiziunali di l'Isula di Corsica, the liner notes explain that members of the group learnt the piece from old singers in Olmi Cappella but have added a new fourth voice (a contra-terza); one of the cadences is also elaborated. ${ }^{37}$ In other recordings there are more subtle differences - at the level of timing or timbre, for instance, or in the character of the melismas. The singers at Olmi Cappella are bemused by the way in which this particular item from their modest repertoire should have become such hot currency. While there is a sense of pride that a part of their local tradition is thus being introduced to a wider audience, there is also a sense of unease that the local nuances of style and interpretation, which for them are an intrinsic part of the piece, might no longer appear as central to its identity. ${ }^{38}$

The treatment of such material by some of the groups who now include it on their own CDs (Olmi Cappella's Agnus Dei is but one example) is clearly derived from a very different view of the past and its meaning. For them, the past is to be respected, certainly, but it is not necessarily considered sacrosanct. They do not, on the whole, share the perspective of the village singers whose attitude, from their own

\footnotetext{
37 Members of Caramusa have also been associated with Olmi Cappella in a research context. Bernardu Pazzoni, director of the Phonothèque at Corte, is a former member of the group; he is now installed in the village with his family.

${ }^{38}$ One singer also expressed the concern that people from outside the island who bought recordings such as those mentioned above might, if they ever found themselves in the village from whose living tradition the material was taken, think that the village singers were "singing it wrong".
} 
vantage point, can tend towards one that is overly purist and possessive. In terms of what gets preserved and becomes "traditional", they would appear to endorse a more liberal view of the past as imperfect and incomplete, subject to the vagaries of fortune and of individual preference, interference or opportunism. The point has also been made that some of the material in question is not necessarily as old as some believe it to be; it was composed by someone somewhere and its adoption by, and continued association with, one particular village may be to some extent an accident of history. ${ }^{39}$ Others have suggested that the status of the surviving repertoires as a precious testimony to the indigenous spirit, together with the fact that the repertoires of so many other villages have now been lost without trace, means that the material is better regarded as the heritage of Corsica as a whole and not that of any one village alone.

There are, moreover, noble antecedents for the practice of recomposition inspired by newly unearthed fragments from the past. Lowenthal, commenting on the Renaissance ideology of refashioning relics into new creations, cites Petrarch's advice to aspiring Renaissance writers: "Take care that the honey does not remain in you in the same state as when you gathered it; bees would have no credit unless they transformed it into something better and better. Thus if you hit upon something worthy while reading or reflecting, change it into honey by means of your style" $(1985,85)$. We might, perhaps, see this as pointing to a different conception of authenticity as a form of creativity that has originality as its end goal, as opposed to absolute faithfulness to that which has been inherited (in the state in which it happens to be at the time of such inheritance). This notion of the desirability of improving on the original also recalls Nando Acquaviva's urge to continue to modify his reconstructions. Mistakes are corrected, effects improved upon; the score is never quite final. In principle, of course, this is in keeping with the organic way in which oral traditions operate - and the "original" reconstructions themselves have, after all, involved the addition of "missing" material, a more or less creative filling of the gaps - yet a certain slippage occurs nonetheless when a particular piece starts to take off in different directions at the same time: the honey will inevitably differ in its colour, flavour and consistency according to the habitat and diet of the bees. There is also an inevitable tension - again, characteristic of oral tradition - between continued

\footnotetext{
${ }^{39}$ It is also the case that material which has long been established as "traditional" in a village in one part of the island might, unbeknown to its practitioners, be derived from the same origin as material similarly fixed in the tradition of another unrelated village in a completely different part of the island.
} 
evolution on the one hand and, on the other, stabilisation into an established and agreed tradition which may, at certain times and from certain perspectives, be viewed as immutable.

It is also the case that, in the work of EVC, there is a heightened preoccupation with the underlying structure of a piece and the theoretical peregrinations to which this gives rise, with the result that some choices may be made on the basis of an aesthetic belonging to the researcher's own perception, which is not only that of an outsider but is also informed by a more eclectic and more academic musical awareness. The singers in Pioggiola and Olmi Cappella are, by their own insistence, not interested in music theory; they don't care what chord progressions they are singing or where they come from. They sing, as they put it, to bear witness to their mass. "It's a testimony," they repeat. They are not there to try to improve on the harmonies, to make the mass sound "more beautiful" or "more Corsican". They are concerned, that is, not with what Peter Kivy (1995) dubs "reasons of the ear" but rather with what we might call reasons of the spirit, reasons of belonging. The melodies and harmonies are, they repeat, but a small part of the whole. What is important is the timbre, the intonation, the breath, the timing, the way that the singers "dance" together, the ebb and flow of the song. Here we might well have recourse to Barthes' concept of the "grain" of the voice - defined as "the materiality of the body speaking its mother tongue" $(1977,182)$ and "the body in the voice as it sings" (188) - and his distinction (following Kristeva) between the pheno-song and the geno-song, the latter being "that apex ... of production where the melody really works at the language" (182). More than anything, what makes the performance of the local singers authentic, from their perspective, is the fact that they are from the village, where the air, the contours of the land, the sounds of nature and the pace of human life have changed relatively little since the mass first saw the light of day. Hence their avowal that "the interpretation that touches us the most is the local one ${ }^{40}$ ... the others transform". ${ }^{41}$

Whilst such cases may be exceptions to the norm, they nonetheless illustrate the complexity of the situation.

40 "Even if there are technical errors," adds Santu Massiani (interview July 2004).

${ }^{41}$ These considerations bring to mind Bernard Lortat-Jacob's work on the psychosocial dimensions of the polyphonic singing traditions of the confraternities of northern Sardinia (Lortat-Jacob 1998). Here, Lortat-Jacob makes a distinction between savoir-faire (which might be glossed as a way of doing, but referring specifically to vocal know-how) and savoir-être (a way of being, and more particularly of living together in community). With respect to the village singers featured in my own discussion, vocal savoir-faire might be viewed as something distinct from musical proficiency, while savoir-être, with its implications of social harmonising, is vital to the success of the enterprise and is, moreover, something that cannot be learnt from a recording. 
The significance of this concept of "song" as not only being constituted by melodic and harmonic material but including, as part of its very essence, factors such as timbre, intonation, timing and breathing cannot be overemphasised. ${ }^{42}$ It is never enough to excavate or to reproduce only the melody line of a piece. If the vision of the researcher or interpreter were to be restricted to the melodic and harmonic structure alone, then the piece $\mathrm{s} /$ he was attempting to bring to life would remain a heap of shards or, at best, a skeletal frame. Only as the full palette of para- and extramusical factors comes into play do the fragments begin to assume form and colour. It is, perhaps, an irony that these features and colorations will, for the most part, be provided by present day singers - but it is those singers rooted in the village who are best placed to be able to do this intuitively. This is also one of the reasons why Nando Acquaviva, in his original work on the Pioggiola mass, took into account other items from the repertoire of the same village.

Those who react against what they see as a purist approach argue that people have always arranged the music in their own way; they are simply continuing that trend. This argument does, of course, side-step questions about differences in meaning when a piece is treated purely as a musical product divorced from its primary setting and from the conditions that created it. The view is, however, not only put forward by those arranging the music for CDs. Pierre Bertoni, prieur of the confraternità of St. Antoine at Calvi, is keen to assert that he knows that they themselves have changed things - in the airs, the versi - and he knows that the old singers changed things too. ${ }^{43}$ This is the nature of an oral culture where nothing is written down. "There is always an interpretation," he insists, "always, always, you understand." The important thing is to be honest: when you make changes, "you must acknowledge it." "For myself," he continues, "I don't feel that I am outside of the tradition. I am in the continuity of the tradition. But I know that there are things that I have added, things that I've taken out, things that I've transformed, out of necessity ... Because if I started to fix things ... that's dogma, it's no longer alive"

\footnotetext{
42 An extreme illustration came to light in the course of a conversation with Nicole Casalonga (September 1994). She described the case of an elderly singer attempting to teach his village mass to a group of younger singers. To his ears, they were never able to get it right: "that's not it", he would repeat, and reportedly said of a mass that they once sang together, "I was singing on my own." What did he perceive, asks Casalonga, as the essential ingredient that the other singers, and she herself as a listener, constantly missed? Was it that he had grown so accustomed to singing in the same fixed ensemble for so many years that he knew intimately every tiny nuance that had characterised the singing of his fellow singers and that no-one else could ever hope to reproduce exactly? Or was it a case of the disjuncture involved in trying to match the living reality of the "new" singers with his less tangible memory of the old?
} 
(interview July 2002). And while the Olmi Cappella and Pioggiola singers are, by their own admission, relatively conservative in their approach, it is not that they are opposed to evolution per se. A concept privileged by Santu Massiani is that of "positive contamination", which he applies to situations where modifications or additions are collectively endorsed by the singers concerned and easily become an organic part of the musical fabric.

\section{The Mass in the Twenty-first Century}

How, then, have these masses fared in recent years? In some of the villages I visited in the mid 1990s, relations between the older men who sang the mass and younger singers in the village were not always easy. Many of the latter had been swept up by the quasi-messianic fervour of the riacquistu and sought above all to emulate the heroic-sounding, "engaged" singing style of the groups, often having their sights set on forming a group and making a CD. Singing the mass and making a meaningful contribution to the religious and cultural life of their village was, for many, an important part of their commitment to their heritage and their desire to express their new-found sense of identity, but many opted to sing the masses of Rusio and Sermano which they had learnt from cassettes or from the scole di cantu rather then spend their time learning from the older singers in their own locality.

In Speloncato, it was not clear whether a sufficient number of young people would come forward to "take the baton" as far as the reconstructed mass was concerned. When I returned to the village in 2002, however, the situation had evolved dramatically. The confraternità of San' Antone Abbate had been formally reinaugurated the previous year, thanks to the combined efforts of several of the present singers and their supporters. A vital role had been played by Pierre Dottori (later to become prieur), a singer from the younger generation who had previously performed with a number of groups but had now turned his energies (Santu Massiani refers to "moral will") to the task of reinvigorating the confraternity. Since its relaunch its 16 members had been working on the mass, the offices and other material - all starting more or less from scratch - under the guidance of Massiani, now retired from his post as schoolmaster in Pioggiola. 44 Some of the singers had

\footnotetext{
${ }^{43}$ Bertoni (currently a teacher of Corsican at Calvi's college) has been involved with these traditions since he was a young boy. He has now devoted several years to translating the Missal into Corsican. 44 In former times the mass was sung in Speloncato not by the confraternità but by the village cantors. Since there are no longer any cantors as such, it is now the confrères who sing; only a few, however, are
} 
also been to the Phonothèque at Corte to listen to Quilici's field recordings. They were now singing for the fêtes patronales of the village and on other special days on which it is customary for the confraternità to be present; they had also undertaken to sing for all funerals (unless the family should wish otherwise). Jean Giovansily, recently returned to the village for his retirement, was learning to sing the terza voice. Even though he had only been singing for six months, he sang - in the words of one of his fellow singers - "with the voice of people a hundred years ago". ${ }^{45}$ The newest recruit, complete with designer denims, flashy trainers and carefully spiked hair, was 9 years old. He was eager to join the confraternità, he told me, because he wanted to learn to sing and to take part in the processions.

A new confraternità had also been formed at the nearby hamlet of Costa (Figure 6), including in its membership a number of men from neighbouring villages which did not, at that time, have an active confraternità of their own. Here, the oldest members looked on with unveiled affection as the youngest singer - also 9 years old attempted a solo line. "What could be more beautiful," sighed Philippe Costa, aged 79, “than to hear this child sing. Ah! But it's marvellous!" (interview July 2002). As at Speloncato, the Costa singers continue to meet for lengthy weekly rehearsals with the help of Santu Massiani. They began by learning a mixture of material from Pioggiola, Olmi Cappella and Moncale. The oldest people in the village still had memories, however, of masses being sung "in the old way" in Costa itself and also in the neighbouring villages of Ville-di-Paraso (Ville-di-Parasu), Occhiatana (Occhjatana) and Palasca, each one different. No traces remain of Costa's own mass, but the 70year-old nephew of a former priest of Occhiatana, now singing at Costa, had begun to recall remnants of Occhiatana's mass. Another inhabitant of Occhiatana, having heard about the activities of the new confraternity at Costa, had proffered a recording of his 80-year-old father (who had been away from the village for 40 years and was now living in Toulon), singing the secunda line of the mass.

The singers immediately began work on the Agnus Dei, again calling on the help of their old friend Nando Acquaviva, who adopted his usual practice of working on alternative proposals for harmonisations to present to the singers for their further consideration. Massiani characterises this way of working as an "exchange of possibilities between a technical proposal and a particular reception in

able to take the lead voices and they are regarded by the others as the real "singers". Meanwhile, the women who contributed to the earlier stage of the revival no longer have a clear role. 
the village", with a balance gradually affirming itself as each piece is "stabilised" (interview June 2002). Again, he is keen to stress that the choices made by the village singers are not primarily musical but are based on emotional factors, informed by a sense of place, the way of life, the manner of pronouncing the words. 46 By the time of my return in 2004, the newly harmonised Agnus Dei and Kyrie were already being sung as part of Costa's mass; the remainder was still under construction, with Santu Massiani and Noel Pardini (then the prieur at Costa) spending long evenings in consultation with Nando Acquaviva, and Pardini himself (who in this case might be seen to represent the "spirit" of the village) also making an active contribution to the proposed harmonisation.

In Pioggiola and Olmi Cappella, the situation is somewhat different. These villages are more isolated than Speloncato and Costa; there are fewer young people and, because of their location, they cannot draw on neighbouring settlements as easily. In the case of Pioggiola, only 20 people - mostly elderly - remain in the village all year round. At the time of my 2002 visit, the oldest singer was already 95 years old; another, in his early 80s, was having trouble with his hearing. A keen young singer who had learnt the mass in the mid 1990s had married and moved away to the Continent. Antoine-Jean Luiggi is as hale and hearty as ever but spends the winter months down in the coastal pastures with his flocks. For special occasions, however, the remaining singers are now joined by some of their younger protégés from Speloncato and Costa.

What Pioggiola had gained at the time of my 2002 visit was a new Credo, the only "movement" that had been missing from the reconstituted mass. Sixtus Carboni (81 years old) described to me how he had composed his Credo in 20 minutes; it came to him, he said, "from the Holy Spirit". Pierre and Raphael, two of the younger singers from Speloncato, promptly came up the mountain and helped him "put it into polyphony"; in an hour it was complete. Now Sixtus' Credo has been integrated into the mass and is, in Santu Massiani's words, "from here". Santu describes Sixtus as belonging to a rare breed of singers who can compose in the traditional style, creating music that is new and ancient at the same time. "His songs could easily be a

\footnotetext{
45 One could say that he sings with the voice of people 200 or 300 years ago, Santu Massiani observes as we revisit my commentary at a later date; and, he stresses, he uses this voice entirely naturally (interview July 2004).

46 Massiani again emphasises that there is no point to the exercise unless people in the village are happy to accept the reconstruction as their own, and concurs with my own observation that the material needs to correspond not only to people's actual memories but also to how they see themselves now and to a past they want to recognise as their own.
} 
hundred years old," he says, and they would indeed probably be taken as such by the casual listener. (Carboni and Massiani interviews July 2002.)

In other parts of the island, newly revived confraternite have also been inspired to revive their villages' musical traditions. In Cap Corse, for example, members of the confraternità at Poretto-di-Brando (Purettu-di-Brandu) have reconstituted a significant body of material, inspired in part by the better-preserved traditions at the neighbouring village of Pozzo-di-Brando. Members of the revived confraternità at nearby Castello-di-Brando (Castellu-di-Brandu) have also been working on the mass and other liturgical material. In 2002 they were singing mainly the mass of Rusio, but also parts of Olmi Cappella and Moncale. 47 There are, however, traces of Castello's own mass and they were reflecting on how best to set about the process of retrieval and reconstitution. By contrast, there are other villages where the mass has already been "saved" but where there is not, at present, a dedicated group of singers who are in a position to work on it. The mass of Muro in the Balagne, for example, was reconstituted by Pierre Oberti in the 1990s but so far nothing further has been done by way of reactivating its practice.

Charles Contri, prieur of the confraternità of Santa Maria Poggio (Santa Maria Poghju) on the eastern edge of the Castagniccia, observes that "there are lots of things currently sleeping on cassettes" - including field recordings made by Félix Quilici, Wolfgang Laade, Markus Römer and, more recently, Bernardu Pazzoni, but also amateur recordings made by miscellaneous individuals which often remain hidden away for years, without anyone else being aware of their existence. Now it's up to the new generation, says Contri, to "take the baton" and to seek out and relearn these masses: they can't simply go on singing Rusio and Sermano indefinitely (interview July 2002). Recordings made by Markus Römer in the 1970s have indeed been sought out by singers in a few villages (they have been given copies), with the result that some material which was no longer sung at the time of Römer's research is now being sung again, thanks to the remnants he was able to collect from isolated older singers, now dead, at a time when there were no younger singers to whom they could pass on their knowledge directly. These recordings have thus proved to be extremely valuable documents in bridging a gap which otherwise might have meant an irreparable break in the chain of transmission.

\footnotetext{
47 Their connection with Moncale is via Tumasgiu Nami from nearby Calenzana, who has been a vital source of support and who often comes and sings with them. Nami (also the village undertaker) has played a key role in the revival of the confraternities in general, lending his practical support to
} 
Many of today's singers - Contri included - are keen to stress their debt to Sermano and, more particularly, to Rusio, whose popularity and accessibility has been reinforced by the wide availability not only of two CDs featuring the Rusio singers themselves (recent re-releases of the original Adès and Auvidis recordings) but also of a disc featuring both the messa di $i$ vivi and the messa di $i$ morti sung by the group I Chjami Aghjalesi (Cantu Sacru, 1991) in a notable departure from their usual politically inspired chanson engagée repertoire. This recording - which, on account of the group's status as one of the leading "cultural groups" and the undying popularity of several of their anthem-like hits, has held a particular appeal for young people - was made with the explicit aim of providing a teaching resource for other young singers. The group wanted to produce a recording, as Paul Félix Nasica explains, that was "very clear", with all the texts ("everything you need") included in the insert (interview July 2004). Because of the ease of acquiring this recording (it is often on sale at supermarkets, stalls at markets and fairs, and garages, as well as dedicated record shops), the Rusio mass has served for many singers as their initiation into singing the mass and singing polyphony; others have learnt it at one of the many scole di cantu. Many have then been inspired to look for traces of their own village repertoires.

Meanwhile, the masses of Sermano and Rusio continue to be widely sung by groups of singers in villages that do not have their own local mass. They also fulfil an important function by serving as a type of common currency among young singers throughout the island who are thus able to form an ad hoc équipe of singers who may not be well acquainted but are still able to sing together. Charles Contri, for example, reports that it is the mass of Rusio that is often sung for funerals in the area around Santa Maria Poggio because this makes it possible to assemble an équipe at short notice - not always a straightforward task since, due to changes in employment patterns, it is no longer easy for the local singers to take time off work in order to sing for a funeral, especially when, in areas with ageing populations, funerals are relatively frequent occurrences (interview July 2002).48 Singing the local mass is

\footnotetext{
groups in different parts of the island as they have embarked on the often related tasks of reinaugurating their local confraternità and learning to sing the mass.

48 It is not unusual, Contri says, to be asked to sing for funerals two or three times a week. (The messe des morts is therefore sung far more often than the messe des vivants.) Another singer described to me how he eventually took the decision to change his job after his boss, somewhat exasperated by his regular absences, had said to him: "Now what are you, a mechanic or a singer?" Other singers have commented on the degree of personal investment involved in attending a funeral as a singer, especially if this takes place in another part of the island: you lose a day's pay, as well as having to cover the cost of petrol and perhaps a meal or two away from home. Many nevertheless regularly
} 
obviously more of a problem if there are only three or four people who know it and the singer of one of the parts is unable to secure time off work. ${ }^{49}$

\section{Reflections and Conclusions: The Past in the Present}

“Pasts belong to people," writes Thomas $(1995,357)$. The trends and processes described in this paper have, I hope, offered useful insights into the ways in which different groups of people in Corsica have set about reclaiming, at a tangible level, aspects of their pasts and, at the same time, restoring aspects of their present, with local musical repertoires in this case serving as the focal point. Just as humanist scholars of the Renaissance conceived of themselves in relation to classical texts as physicians healing a broken past (Lowenthal 1985, 84), so in Corsica many of those engaged in the reconstruction of the musical heritage see themselves as mending shattered links in the chain of transmission. And, like Lowenthal's "healing humanist" who healed himself as well as a more objective past, they have set about "reconstituting out of the fragments of [their] own past an identity that combine[s] a consciousness at once old and new" $(1985,85)$. For those involved, the perception of the mass settings as constituting a vital part of their heritage accounts both for the intimation of their value and for a sense of moral responsibility with respect to their preservation - not simply, however, as artefacts in a museum. Heritage in itself - as the term suggests - implies a movement from past to future: it is defined in UNESCO's "Convention concerning the Protection of the World Cultural and National Heritage" (1997) as "our legacy from the past, what we live with today, and what we pass on to future generations" (cited in Skeates 2000,11). The success of the revival and reconstruction projects has, as we have seen, depended crucially on their coincidence with a renewed interest on the part of the younger generation to take on the traditional ways as their own.

One thing that becomes clear as a common factor uniting many of the different stories alluded to here is the importance of key individuals, both initiators

\footnotetext{
travel considerable distances in order to help out their friends and to maintain what they see as a vital tradition and service.

${ }^{49}$ These problems can also affect the messe des vivants when a particular feast falls on an ordinary working day or when the extreme shortage of priests afflicting many inland areas means that even the main feasts, which might normally coincide with a public holiday, have to be celebrated in a number of neighbouring villages at different times, including a day before or after the feast itself. By dint of the same problem, in a significant proportion of villages it is no longer possible to ensure a regular weekly mass; in some places the mass is celebrated only once a month. Again, this has a knock-on effect in terms of the singing tradition.
} 
at a local level and those professionals whose skills have been put at their service. The work of EVC and Annie Goffre, which continues to be pursued in other parts of the island, ${ }^{50}$ has made an important contribution to research into traditional music in Corsica in general and, in directly practical terms, to the musical life of the villages concerned: the masses are once again being sung for feast days and funerals by groups of local singers who are passing them on to the younger generation in the traditional manner. Despite the fact that many of the reconstructions have passed through a written stage - in some cases, one of deliberate recomposition - what is of interest now is the way in which much of this material has once again returned to the world of orality and become subject to its laws, remaining open to change as it is personalised by each new generation of singers and adapted to prevailing conditions, thereby providing proof that the tradition has not become ossified but continues to function as part of a living culture. In many cases, it has been necessary to jump a generation of singers who were either absent or uninterested in maintaining the continuity of these practices; in this case the reconstruction initiative has effectively served to bridge the gap. Even so, while the continuity of actual practice might have been broken for the various reasons outlined in the preceding discussion, some of the local people who themselves were part of the "lost" past are still alive today and so serve as a direct link between past and present. It would therefore seem more accurate to speak of a disruption rather than a clean break: the track was put on pause while the singers took an extended leave of absence. Admittedly, it was not just like the hundred years' slumber of Sleeping Beauty, a mere hitch in the movement of the muscle, a catch in the breath, youth preserved untarnished while the thicket grew all around. As with the other characters in the fairy tale, there was deterioration and decay - in the memory, in the psychosocial fabric; the singers themselves aged. But some of them did live in the past and that past is, to them, not necessarily a foreign country.

The active part played by people in shaping the cultural remains whose restoration is now seen as desirable is again evoked by Fowler. "If only people in the past had kept it simple," he says, with respect to the material heritage, "... but of course they changed and adapted their building through time just as we continue to do " $(1992,12)$. The task is complex enough when we are dealing with tangible, material objects. Trying to trace the exact genesis of a piece of music is virtually an impossible task, and not only because of the absence of tangible records. An

\footnotetext{
${ }^{50}$ Goffre has since published a study of the mass of the southern town of Sartène (2002).
} 
investigation into the more recent evolution of the material reveals an inevitably complicated network of interrelations, interpolations, adaptations and reappropriations, and in many respects there is nothing new about this. A musical repertoire is built up of a continuing accumulation of small adjustments and improvements, innovations and stylistic cross-fertilisations in a sense where such terms should not be seen as being negatively loaded. Corsican singers often say of what they are doing: "On interprète." They are not simply reproducing the material, nor are they changing it as such; they are "interpreting" it in a way that is true to their own reality. Inevitably, perhaps, the perception of the parameters delineating such interpretation is somewhat flexible, with the result that, as we have seen, different discourses coexist, with some stressing the importance of the material being sung by people from the village in question while others argue for continuous borrowing and adaptation as a time-honoured tradition in its own right. There is, in any case, no real foundation for viewing the past as unchanging (and, by extension, sacrosanct): it is simply that the workings of the present are more transparent and some of the changes are perhaps more self-conscious. An examination of contemporary developments as they occur can usefully illuminate the way in which things might have worked in the past - in archaeological terms, this relates to the theory of uniformitarianism, which states that events of the past must be explainable by processes that can be observed to operate in the world today. Sixtus' Credo also offers food for thought in this context. It does not sound any less "ancient" than the rest of Pioggiola's mass, yet it was composed in the 21st century. Does this make any difference? Is this material less "authentic" than more "ancient" settings (now anonymous perhaps, but once composed by someone, somewhere)?

As far as the "relics" from the more distant past are concerned, the present generation has succeeded in piecing together the shattered shards, allowing the muscles to flex again as today's singers breathe life into the bones. The sound has once more become articulated and embodied; it moves again in three-dimensional space. What we are hearing, however, is not just the voices of the past. The chain might have been broken, the fabric might have fragmented, but the grain is still there in the voices of today's singers. They might sing "with the voices of people a hundred years ago", but these voices have not been deliberately distressed; no-one has added a patina of age and authenticity. There is nothing decadent about their use of supposedly "archaic" formulae. Their product is not a replica. This is how they sing, how they compose, today, in the 21st century. This is the voice of their present. 


\section{Acknowledgements}

I am indebted to the British Academy not only for funding my fieldwork of summer 2002, dedicated more or less exclusively to research into the Corsican masses and the revival of the confraternities, but also for supporting my original $\mathrm{PhD}$ work on which this paper also draws. For support for my latest fieldwork trip (2004), I am grateful to the British Academy, Music and Letters Trust and the University of Wales, Bangor. Amongst my Corsican collaborators, I am indebted to the innumerable members of the various singing ensembles and confraternities mentioned in this paper for their generous and serious response to my enquiries and for their unfailingly warm welcome. Special thanks in this instance are due to Santu Massiani with whom, over the years, I have enjoyed many stimulating discussions, and to his fellow singers at Pioggiola and Olmi Cappella for their hospitality during my many visits; to Elisabeth Pardon for sharing her knowledge and enthusiasm as well as welcoming me initially to Speloncato; to Nicole Casalonga for earnest discussions on numerous occasions concerning EVC's part in the reconstruction projects (and much more besides); and to the present singers of Speloncato and Costa who allowed me to be present at a series of their weekly rehearsals in June/July 2002. Finally, I am grateful to Bernard Lortat-Jacob and Martin Stokes for their comments on an earlier draft of this article.

\section{References}

Acquaviva, Nando, Nicole Casalonga, Annie Goffre, Antoine Massoni and Sébastien Rubellin. 1996. Polyphonies corses: l'orgue et la voix. Paris: Éditions L'Harmattan. Anon. 1976. Sur les machines sonores à remonter le temps. Kyrn 61: 51-2.

Barthes, Roland. 1977. The grain of the voice. In Image Music Text. (English translation Stephen Heath.) London: Fontana Press.

Buchli, Victor A. 1995. Interpreting material culture: the trouble with text. In Interpreting archaeology: finding meaning in the past, edited by Ian Hodder et al. London and New York: Routledge, pp. 181-93.

Butt, John. 2002. Playing with history. Cambridge: Cambridge University Press.

Chailley, Jacques. 1982. La messe polyphonique du village de Rusio. Revue de Musicologie 68: 164-73. 
Centre d'Ethnologie Française-Musée National des Arts et Traditions Populaires and

E Voce di u Cumune. 1992. Contributions aux recherches sur le chant corse I: polyphonies vocales et orgue. With cassette. Paris: CEF-MNATP.

Fowler, Peter J. 1992. The past in contemporary society: then, now. London: Routledge.

Gellner, Ernest. 1995. Interpretive anthropology. In Interpreting archaeology: finding meaning in the past, edited by Ian Hodder et al. London and New York: Routledge, pp. 48-50.

Goffre, Annie. 1993. Néopolyphonies, pourquoi? In Polyphonies de tradition orale: histoire et traditions vivants (Actes du Colloque de Royaumont, 1990), edited by Christian Meyer. Paris: Éditions Créaphis, pp. 85-99. . 2002. La Messe de Sartène et au delà. Contributions aux recherches sur le chant corse II. Calvi: E Voce di u Cumune.

Gregori, Jacques. 1991. De Festivoce à Vatican II. Kyrn 367: 41.

Kivy, Peter. 1995. Authenticities - philosophical reflections on musical performance. Ithaca: Cornell University Press.

Lortat-Jacob, Bernard. 1998. Chants de Passion: au coeur d'une confrérie de Sardaigne. Paris: Les Éditions du Cerf.

Lowenthal, David. 1985. The past is a foreign country. Cambridge: Cambridge University Press.

Pérès, Marcel. 1987. Liner notes to E Voce di u Cumune, Corsica: Chant Polyphoniques. (See discography)

Redknap, Mark. 2002. Re-creations: visualising our past. Cardiff: National Museum of Wales and Cadw: Welsh Historic Monuments.

Römer, Markus. 1983. Schriftliche und mündliche Traditionen geistlicher Gesänge auf Korsika. Wiesbaden: Franz Steiner Verlag.

Skeates, Robin. 2000. Debating the archaeological record. London: Duckworth.

Thomas, Julian. 1995. Where are we now?: archaeological theory in the 1990s. In Theory in archaeology: a world perspective, edited by Peter J. Ucko. London and New York: Routledge, pp. 343-62.

\section{Discs cited}

A Cumpagnia. 1994. Missa Corsica in Monticellu. K617043.

A Filetta. 1992. Ab Eternu. Saravah 591061.

Caramusa. 1990. Canti e Musica Tradiziunali di l'Isula di Corsica. Ricordu CDR 062. 
Corsica: Religious Music of Oral Tradition from Rusiu. 1978. Auvidis/Philips 6586033. Released 1989 by Unesco D 8012. (Recorded 1975.

E Voce di u Cumune. 1987. Corsica: Chants Polyphoniques. Harmonia Mundi HMC 901256.

I Chjami Aghjalesi. 1991. Cantu Sacru. Ricordu CDR 073.

Messa Corsa in Rusiu. N.d. Adès 10 007. (Recorded 1959.)

Messa Nustrale in Sermanu. 1977. Consul XCMX 19705. Rereleased 1990 by Consul CM 88-08. (Recorded 1977.)

A number of items from the liturgical repertoires of different villages can be found in the field recording collections of Quilici, Laade, Römer, Pazzoni and others, copies of which are housed at the Phonothèque of the Musée de la Corse in Corte. My own recordings are not, at present, available for public consultation.

\section{Interviews cited}

Bertoni, Pierre. Calvi, July 2002.

Carboni, Sixtus. Pioggiola, July 2002.

Casalonga, Nicole. Pigna, November 1994.

Casalonga, Nicole. Pigna, July 2004.

Contri, Charles. Folleli, July 2002.

Costa, Philippe. Costa, July 2002.

Massiani, Santu. Olmi Cappella, June 2002.

Massiani, Santu. Pioggiola, July 2002.

Massiani, Santu. Pioggiola, July 2004.

Nasica, Paul Félix. Poggio di Venacu, July 2004.

Pardon, Elisabeth. Belgodère, July 2004.

Vuillamier, Max. Lumio, July 2002. 